\title{
Cyanotoxins: from poisoning to healing -a possible pathway?
}

\author{
Elsa Dias* and Sérgio Paulino and Paulo Pereira \\ Instituto Nacional de Saúde Dr. Ricardo Jorge, Av. Padre Cruz 1649-016 Lisboa, Portugal. \\ * Corresponding author: elsa.dias@insa.min-saude.pt
}

Received: 03/02/2014

Accepted: 26/03/2014

\begin{abstract}
Cyanotoxins: from poisoning to healing -a possible pathway?

Cyanobacteria are photosynthetic microorganisms known for their multiple, and occasionally dual, ecologic roles. Cyanobacteria are major contributors to oxygen production on earth, but they often bloom in freshwater environments, depleting oxygen and inducing massive fish kills by anoxia. In addition, cyanobacteria are primary producers and the base of the food web in aquatic ecosystems, but they often "crowd out" other phytoplanktonic organisms by competing for nutrients. Cyanobacteria produce an array of beneficial, biologically active compounds, but some of their secondary metabolites are also known to be highly toxic to humans. Many cyanobacterial characteristics are still a mystery and raise many unsolved questions: Why do they bloom? How do they "communicate" with each other and "synchronise" to flourish? How do they colonise so many diverse habitats and are resistant to the most adverse of environments? Why do some strains produce toxins while others do not? Current research on cyanobacteria may provide answers to these "old" questions, but may also challenge us to consider new perspectives. In this paper, we will discuss the potential therapeutic application of cyanobacterial toxins, most of which are known as potent toxicants, but some of which have a non-negligible potential for drug discovery.
\end{abstract}

Key words: Cyanotoxins, health, new drugs.

\section{RESUMEN}

\section{Cianotoxinas: de venenos a medicamentos -una vía posible}

Las cianobacterias son microorganismos fotosintéticos conocidos por sus múltiples y a veces opuestos, roles ecológicos: son importantes contribuyentes en la producción de oxígeno en la Tierra, pero a menudo tienen floraciones en ambientes de agua dulce y llegan a agotar el oxígeno del agua, en este caso inducen la muerte masiva de peces por anoxia; son productores primarios y la base de la cadena alimenticia en los ecosistemas acuáticos, pero a menudo impiden la presencia de otros organismos fitoplanctónicos con los que compiten por los nutrientes disponibles; producen una amplia diversidad de compuestos biológicamente activos explotables para aplicaciones útiles, pero algunos de sus metabolitos secundarios también son conocidos por ser altamente tóxicos para los seres humanos. Muchas características de las cianobacterias son todavía un misterio y plantean muchas preguntas sin resolver: ¿por qué tienen floraciones? ¿cómo se comunican entre sí y se sincronizan para producir floraciones? ¿cómo se las arreglan para colonizar hábitats tan diversos y resistir en los entornos más adversos? ¿por qué algunas cepas producen toxinas, mientras que otras no lo hacen? etc. La investigación actual sobre cianobacterias puede dar respuestas a esas preguntas antiguas, pero también puede desafiarnos para debatir nuevas perspectivas. En este artículo discutiremos la posible aplicación terapéutica de las cianotoxinas, más conocidas por ser tóxicos potentes aunque empiezan a mostrar tímidamente una potencialidad creciente en el descubrimiento y desarrollo de nuevos fármacos.

Palabras clave: Cianotoxinas, salud humana, nuevos fármacos.

\section{CAN CYANOTOXINS KILL?}

Toxin production by cyanobacteria has garnered the attention of the scientific community for many decades. A recent bibliometric study reported that more than 5000 papers on cyanotoxins were published prior to 2012 (Merel et al., 2013). Meanwhile, the ecologic role of 
cyanotoxins is still under debate, and many hypotheses have been proposed that indicate a competitive advantage to or a physiological function of toxin production (Holland \& Kinnear, 2013). Indubitably, one of the most intriguing aspects of cyanotoxins is their toxic action upon organisms that are not direct predators of cyanobacteria, such as mammals and humans. Much data have been reported and discussed on the negative impact of cyanotoxins on human health (Chorus et al., 2000; Duy et al., 2000; Apeldoorn et al., 2007), but many doubts persist regarding the real effects of these compounds on human populations.

In some countries, the risk of acute intoxication by cyanotoxins is most likely negligible, given that proper water treatment and water quality surveillance programs ensure that populations are not exposed to high levels of cyanotoxins (Codd et al., 2005). However, for economic/geographic reasons, many populations still drink untreated water, and in these cases, the occurrence of cyanotoxins is certainly underevaluated. According to the WHO statistics in 2013, impressive progress has been observed in the last two decades concerning access to treated water. Nevertheless, significant disparities remain between regions, and 1.1 billion people still have no access to any type of improved drinking water source (WHO, 2013). In some countries, the issue of cyanobacteria/cyanotoxins is restricted to academic circles, and even when monitoring programs are implemented, they are often limited by the demands on analytical resources (Cood et al., 2005). In Europe, medical case-reports on human intoxications are sporadic, and no human fatalities have been attributed to cyanotoxins. However, even in countries with adequate monitoring programs, the risk of continuous exposure to low levels of cyanotoxins remains unevaluated (Spoof, 2005). Such chronic exposure to water that is contaminated with residual levels of cyanotoxins is particularly relevant for the case of potentially carcinogenic compounds such as microcystins, nodularin and cylindrospermopsin (Žegura et al., 2011). A first guideline value of $1.0 \mu \mathrm{g} \mathrm{L}^{-1}$ for microcystin-LR in drinking water was proposed by the WHO in 1999 based on a Tolerable Daily Intake of $0.04 \mu \mathrm{g} \mathrm{kg}^{-1}$ of bw/day (Duy et al., 2000; Funari \& Testai, 2008). At that time, given that toxicological studies were not sufficiently consistent, the WHO did not include a guideline for chronic effects. Updated data led the USA Environmental Protection Agency (U.S.EPA) to set a seven-fold lower acute TDI level (0.006 MC$\mathrm{LR} \mu \mathrm{g} \mathrm{kg}^{-1}$ of bw/day) and to propose for the first time a chronic TDI level (0.003 MC-LR $\mu \mathrm{g}$ $\mathrm{kg}^{-1}$ of bw/day), thus recognising microcystins as potential contributors to human chronic pathologies (U.S.EPA, 2006). However, many uncertainties still persist. It is known that microcystins induce acute hepatotoxicity through the inhibition of protein phosphatases PP1/PP2A and oxidative stress (Campos \& Vasconcelos, 2010) and function as tumour promoters, most likely though the deregulation of mitogen-activated protein kinases and the activation of protooncogens (Gehringer, 2004; Li et al., 2009; Dias et al, 2010). It has also been hypothesised that microcystins are genotoxic agents (Žegura et al., 2011) and, consequently, tumour initiators. In 2006, the International Agency for Research on Cancer (IARC) classified MC-LR as a possible carcinogen for humans (group 2B) (IARC, 2006); however, the epidemiologic evidence concerning its carcinogenicity is scarce, and available studies are inadequate for proposing a guideline for carcinogenicity (U.S.EPA, 2006). Namely, confounding risk factors associated with other contaminants or organisms were not ruled out, and information about the levels of exposure are limited (IARC, 2006). Consequently, an unequivocal cause-effect relationship between human exposure to microcystins and cancer development has not yet been established. We assume, therefore, that microcystins are harmful to human health, but we still do not know how to evaluate and manage the risks of microcystins. The toxicological knowledge concerning other toxins is even more limited but, based on local requirements, guidelines for other cyanotoxins have been implemented in a few countries, even with significant discrepancies that imply that doubts still exist regarding the effects of toxins on human populations (Burch, 2008). 
Why does our knowledge about the impact of cyanobacteria on human health remain so limited even though toxicology (24\%), ecology (19\%), chemistry $(18 \%)$ and pharmacology $(17 \%)$ constitute the main research areas for cyanotoxins (Merel et al., 2013)? In fact, the 5\% share of "public health and epidemiology" among the literature concerning cyanotoxins elucidates the relatively low percentage of scientific focus given to health issues (Merel et al., 2013). Epidemiology is certainly hindered by the following: 1) the absence of specific biomarkers of exposure/effect for the different toxins (Batoréu et al., 2005); 2) the fact that exposure is presumably diminished where adequate surveillance and early warning systems are implemented; and 3) analytical limitations; e.g, analyses of complex matrices, such as animal/human tissues, require the use of relatively complex methods (tandem mass spectrometry), while most screening methods have limited sensitivity and selectivity to detect toxins below the U.S.EPA chronic TDI levels.

Moreover, it seems that despite the dependence of humanity on water supplies, a low level of attention is devoted by many governments to the issue of the impact of cyanobacteria/cyanotoxins on water quality and health (Codd et al., 2005). Occurrences and impacts are not really evaluated worldwide and are most likely underestimated, which can be demonstrated by the fact that only 12 countries are responsible for more than $90 \%$ of worldwide research on cyanotoxins (Merel et al., 2013). Moreover, the scientific community dedicated to this issue is small (Codd et al., 2005), likely reflecting the low diversity of scientific areas involved. Most importantly, the financial support for research on cyanotoxins comes mostly from public entities (government agencies, national institutes, foundations, ministries, etc.), and limited funding is certainly related to the lack of potential commercial applications for cyanotoxins.

Lately, however, there has been some evidence arising from clinical and experimental studies that indicates that this scenario may change in the coming years.

\section{CAN CYANOTOXINS HEAL?}

The search for biologically active secondary metabolites for medical purposes, including therapeutic drugs, is not new. In fact, nature has been recognised as an important source of potential drugs since ancient times, well before their active principles were first isolated and identified. Potent toxins such as atropine, morphine and colchicines were among the first active compounds to be isolated, and some are still considered to be essential drugs in medical practice and health care systems. Throughout the $20^{\text {th }}$ century, many other life-saving drugs, including antibiotics, immunosuppressants, anticancer drugs, etc., have been developed from active human exploitation of natural sources. Even today, the majority of new chemical entities introduced as drugs in the market are derived or inspired from natural products (Newman \& Cragg, 2012). This clearly demonstrates the central role that these compounds continue to play as major platforms for the discovery of new front-line drugs.

After Fleming's discovery of penicillin, the main focus of pharmaceutical research for natural products has been on microbial sources. Cyanobacteria have a long evolutionary history and constitute a unique group of ubiquitous oxygenic, photosynthetic bacteria that are capable of colonising a vast diversity of ecological niches. It is therefore reasonable to assume that cyanobacteria have evolved to create a large pool of active compounds with diverse structures and functions. In fact, cyanobacteria's potential as a new source of bioactive molecules has been actively examined, mostly during the last two decades. Hundreds of cyanobacterial compounds have been recently identified, some being associated with antibacterial, antiviral, or antitumor activities, among other properties (revised in Singh et al., 2011; Costa et al., 2012), as exemplified in Table 1. However, despite their potent biological activities, very few cyanobacterial compounds have entered clinical trials, and no cyanobacterial-derived compound has ever 
Table 1. Cyanobacterial metabolites and potential pharmacologic/medical applications. Metabolitos de cianobacterias y sus potenciales aplicaciones farmacológicas/médicas.

\begin{tabular}{|c|c|c|c|}
\hline Metabolite & Class & Activity/target & Reference \\
\hline \multicolumn{4}{|l|}{ Antiviral } \\
\hline Spirulan & polysaccharide & \multicolumn{2}{|l|}{ HIV-1, HIV-2, HSV, Influenza } \\
\hline Nostoflan & polysaccharide & \multicolumn{2}{|l|}{$\begin{array}{l}\text { HSV-1, HSV-2, } \\
\text { Cytomegalovirus, Influenza, } \\
\text { Adenovirus , Coxsackievirus }\end{array}$} \\
\hline Cyanovirin-N & lectin & \multicolumn{2}{|c|}{$\begin{array}{l}\text { HIV-1, HIV-2, SIV, FIV, HSV-6, } \\
\text { Measles virus }\end{array}$} \\
\hline Scytovirin N & polypeptide & \multicolumn{2}{|l|}{ HIV-1 } \\
\hline Sulfoglycolipid & glycolipid & \multicolumn{2}{|l|}{ HIV-1 } \\
\hline \multicolumn{4}{|l|}{ Antibacterial } \\
\hline Noscomin & diterpenoid & \multicolumn{2}{|l|}{$\begin{array}{l}\text { Bacillus cereus, Staphylococcus } \\
\text { epidermidis, Escherichia coli }\end{array}$} \\
\hline Carbamidocyclophanes & paracyclophanes & \multicolumn{2}{|l|}{ Staphylococcus aureus } \\
\hline Ambiguine I isonitrile & alkaloid & $\begin{array}{l}\text { E. coli, S. aureus, Bacilllus } \\
\text { subtilis }\end{array}$ & Singh et al., 2011 \\
\hline Norbiethanediterpenoid & diterpenoid & \multicolumn{2}{|l|}{ Staphylococcus aureus } \\
\hline Phenolic compound & phenolic compound & \multicolumn{2}{|l|}{$\begin{array}{l}\text { B. subtilis, B. cereus, E. coli, } \\
\text { Salmonella typhi, S.aureus }\end{array}$} \\
\hline Hapalindole T & alkaloid & \multicolumn{2}{|l|}{$\begin{array}{l}\text { S. aureus, Pseudomonas } \\
\text { aeruginosa, S. typhi, E. coli }\end{array}$} \\
\hline Pahayokolide A & cyclic peptide & \multicolumn{2}{|l|}{ Bacillus sp. } \\
\hline Fatty acids & fatty acids & \multicolumn{2}{|l|}{$\begin{array}{l}\text { B. subtilis, } \text { S. aureus and } \\
\text { Micrococcus flavus }\end{array}$} \\
\hline \multicolumn{4}{|l|}{ Antiprotozoal } \\
\hline Viridamide A & lipopeptide & $\begin{array}{l}\text { Trypanossoma cruzei, } \\
\text { Leishmania mexicana, } \\
\text { Plasmodium falciparum }\end{array}$ & \\
\hline Symplocamide A & depsipeptide & $\begin{array}{l}\text { T. cruzei, Leishmania } \\
\text { donovani,P. falciparum }\end{array}$ & Singh et al., 2011 \\
\hline Venturamides & cyclic hexapeptides & \multicolumn{2}{|l|}{ P. falciparum } \\
\hline Dragomabin & lipopeptide & \multicolumn{2}{|l|}{ P. falciparum } \\
\hline Ambigol C & chlorinated aromatic compound & \multicolumn{2}{|l|}{$\begin{array}{l}\text { P. falciparum,Trypanosoma } \\
\text { rhodesiense }\end{array}$} \\
\hline \multicolumn{4}{|l|}{ Anticancer/antitumoral } \\
\hline Cryptophycin 1 and 52 & cyclic depsipeptides & \multicolumn{2}{|l|}{ breast/lung cancer cell lines } \\
\hline Curacin A & lipopeptide & \multicolumn{2}{|l|}{$\begin{array}{l}\text { inhibiton of microtubule } \\
\text { assembly }\end{array}$} \\
\hline Dolastatin 10, 15 and analogues & depsipeptides & \multicolumn{2}{|l|}{ affects microtubule assembly } \\
\hline
\end{tabular}


Table 1. (cont.) Cyanobacterial metabolites and potential pharmacologic/medical applications. Metabolitos de cianobacterias y sus potenciales aplicaciones farmacológicas/médicas.

\begin{tabular}{|c|c|c|c|}
\hline Metabolite & Class & Activity/target & Reference \\
\hline \multicolumn{4}{|l|}{ Anticancer/antitumoral } \\
\hline Apratoxins & cyclic depsipeptides & G1 phase cell cycle arrest & \\
\hline Tolyporphin & porphyrin & photosensitizers of tumor cells & $\begin{array}{l}\text { Singh et al., 2011; } \\
\text { Costa et al., } 2012\end{array}$ \\
\hline Somocystinamide A & lipopeptide dimer & citotoxic for neuroblastoma cells & \\
\hline Aurilide B & cyclic depsipeptide & microfilament disruption & \\
\hline Belamide A & tetrapeptide & $\begin{array}{l}\text { microtubule disruption, actin } \\
\text { filament stabilization }\end{array}$ & \\
\hline Calothrixins & $\begin{array}{l}\text { pentacyclic } \\
\text { indolophenanthridine }\end{array}$ & $\begin{array}{l}\text { cell cycle inhibition, oxidative } \\
\text { stress }\end{array}$ & \\
\hline Coibamide A & cyclic depsipeptide & cell cycle inhibition & \\
\hline Hectochlorin & lipopeptide & cell cycle inhibition & \\
\hline Lyngbyabellin A and B & cyclic depsipeptide & $\begin{array}{l}\text { cell cycle inhibition, } \\
\text { microfilament disruption }\end{array}$ & \\
\hline Lyngbyastatins & cyclic depsipeptide & $\begin{array}{l}\text { microfilament disruption, serine } \\
\text { protease inhibition }\end{array}$ & \\
\hline Symplocamide & cyclic peptide & $\begin{array}{l}\text { serine protease inhibition, cell } \\
\text { cycle inhibition, microtubule } \\
\text { depolimerization }\end{array}$ & \\
\hline Symplostatins 1 and 3 & pentapeptide & $\begin{array}{l}\text { Bcl-2 fosforilation, caspase- } 3 \\
\text { stimulation, microtubule } \\
\text { depolimerization }\end{array}$ & \\
\hline \multirow[t]{2}{*}{ Microcystins } & cyclic heptapeptides & $\begin{array}{l}\text { induction of aberrant mitotic } \\
\text { spindles }\end{array}$ & Lankoff et al., 2003 \\
\hline & & $\begin{array}{l}\text { potent cytotoxicity in } \\
\text { OATP's-transfected HeLa cells }\end{array}$ & Monks et al., 2007 \\
\hline \multicolumn{4}{|l|}{ Analgesic/anesthesic } \\
\hline Neosaxitoxin & alkaloid & local anesthesia & Rodriguez-Navarro et al., 2007 \\
\hline Gonyautoxins & alkaloids & $\begin{array}{l}\text { pain relief in tension-type } \\
\text { headache }\end{array}$ & Lattes et al., 2009 \\
\hline \multicolumn{4}{|l|}{ Antiparkinsonian } \\
\hline $\begin{array}{l}\text { RVSF analog peptide } \\
\text { (based on MCLR-ADDA } \\
\text { side chain) }\end{array}$ & cyclic heptapeptide & $\begin{array}{l}\text { modulating agent of PP1 in } \\
\text { Parkinson disease }\end{array}$ & $\begin{array}{l}\text { Tappan \& Chamberlin, } 2008 \\
\text { Braithwaite } \text { et al., } 2012\end{array}$ \\
\hline \multicolumn{4}{|l|}{ Muscle relaxant } \\
\hline Neosaxitoxin & alkaloid & $\begin{array}{l}\text { reversible relaxing effect in } \\
\text { esophageal sphincter in patients } \\
\text { with alchalasia }\end{array}$ & Rodriguez-Navarro et al., 2006 \\
\hline Gonyautoxins & alkaloids & $\begin{array}{l}\text { reversible anal sphincter } \\
\text { relaxation in patients with anal } \\
\text { fissure }\end{array}$ & Garrido et al., 2005 \\
\hline
\end{tabular}


been approved by the European Food Safety Authority (EFSA) in Europe or by the Food and Drug Administration (FDA) in the United States.

Perhaps the most promising cyanobacterial secondary metabolites that were once considered leading candidates for an anti-cancer drug were the Nostoc sp. compounds called cryptophycins. Cryptophycin A was first isolated by a group from Merck, with the intention of using it as an antifungal agent. Later, cryptophycins were reported as one of the most potent tubulin destabilising agents, capable of arresting tumour cells at the G1-M phase (Smith et al., 1994) and causing hyper-phosphorylation of Bcl-2, which triggers the apoptotic cascade (Lu et al., 2001). Following such promising results, a synthetic analogue named cryptophycin 52 entered phase II of a clinical trial. However, the initial tests indicated severe toxicity and prevented further developments with this molecule as an anti-cancer treatment (Edelman et al., 2003).

Cryptophycins are just one among thousands of candidate molecules that fail to meet the safety criteria of clinical trials before reaching the approval of drug authorities. It has been estimated that the pharmaceutical industry has to spend approximately 400 to 1800 million euros to bring a new chemical entity as a new drug into the market (Adams \& Branter, 2006), and such high costs are reflected in the scarcity of new drugs that are available for increasing numbers of diseases. Interest in cyanobacteria metabolites has still a long way to trek and dificulties such as those seen with cryptophycins should not hamper further research on this topic.

One of the most interesting and perhaps unique breakthroughs concerning the therapeutic use of cyanobacteria secondary metabolites in human illness comes from the most potent toxins associated with these organisms, the Paralytic Shellfish Toxins. It may be perplexing at first that a highly toxic family of compounds turns out to be a good candidate for pharmaceutical purposes, but the use of potent natural toxicants is not new in drug discovery. Botulinum toxin is a recent example: “... once a food poison and latter exploited as a biological weapon, is currently one of the most versatile pharmaceuticals for the treatment of human diseases in ophthalmology, neurology and dermatology" (Ting \& Freiman, 2004).

\section{Saxitoxins and derivatives}

The parallelism between Botulinum toxin and Paralytic Shellfish Toxins is notorious: they are both potent neurotoxins, they first became notorious as food contaminants, leading to many deaths worldwide, they have both been exploited as biological/chemical weapons, and now, both are being exploited for medical use.

Paralytic shellfish toxins (PST) are potent neurotoxic alkaloids that are produced by freshwater cyanobacteria and marine eukaryotic dinoflagellates. PST share a common tricyclic structure based on a 3,4,6-trialkyltetrahydropurine skeleton and form a family of more than 50 known analogues with different substituent side chains (Wiese et al., 2010). PST act by binding voltage gated sodium ion channels in neuronal cells through reversible interaction with a neurotoxin receptor on the extracellular side of the channel (Cestèle \& Catterall, 2000). Such interaction blocks sodium influx through the cell membrane, preventing the generation/propagation of electrical impulses in these excitable cells, leading to muscle paralysis. Saxitoxin, the first identified PST analogue, is one of the most potent natural neurotoxins known to date, exhibiting an $\mathrm{LD}_{50}$ in mice (i.p.) of $10 \mu \mathrm{g} / \mathrm{Kg}$ b.w. (Deeds et al., 2008) and a human lethal dose of $1 \mathrm{mg}$ of saxitoxin equivalents (Wiese et al., 2010). PST accumulates through aquatic food webs, and the ingestion of contaminated molluscs (the most traditional PST vectors) leads to a potentially fatal syndrome known as Paralytic Shellfish Poisoning (PSP). After ingestion, toxins are readily absorbed, and systemic distribution occurs in less than an hour, producing the following known sequence of symptoms: paresthesia and numbness of the lips, mouth, face and neck; muscular weakness; sensation of lightness and floating; ataxia; motor incoordination; drowsiness; incoherence; progressively decreasing ventilator efficiency; and eventually death if artificial ventilation is not immediately available (Deeds et al., 2008). 
Symptoms of PSP result from the systemic distribution of the ingested toxins. However, when applied locally (by intramuscular injection -i.m.), STX and its analogues induce muscular relaxation (flaccid paralysis) for periods that are dose-dependent (Kao, 1966). Based on these local actions, researchers from the University of Chile have recently proposed new therapies based on PST injection (i.m. or s.c.) at low doses to treat a number of medical disorders that result from sustained involuntary muscular contraction.

One of those disorders is achalasia, a gastrointestinal motility disorder characterised by a failure of the lower esophageal sphincter (involuntary) to relax during swallowing due to damage in the neural network of the myenteric plexus in the lower two thirds of the esophagus. The musculature of the lower esophagus remains spastically contracted because the myenteric plexus has lost its ability to transmit a signal to cause "receptive relaxation" (Goyal, 2005). In a pilot study involving 2 patients with a diagnosis of achalasia, Rodriguez-Navarro et al. (2006) showed that neosaxitoxin injected into the endoscopically estimated lower esophageal sphincter produced an immediate and reversible relaxing effect on the muscle. Symptoms resulting from achalasia (dysphagia, regurgitation and chest pain) were significantly relieved 2 hour after injection, and patients stayed asymptomatic for 48 hours with no signs of inflammatory reaction to neosaxitoxins (Rodriguez-Navarro et al., 2006). The prospective nature of the study was noted, but no further developments were published.

Another medical disorder in which these toxins have proven to be good candidates as an alternative to other conservative treatments is anal fissure (Garrido et al., 2005). Anal fissure begins as a linear split in the long axis of the distal anal canal and generally follows a trauma associated with defecation (Lund \& Scholefield, 1996). Anal fissure can be acute or chronic. Acute anal fissure is treated conservatively with dietary modification and tends to heal within 1 to 2 weeks. However, continuous irritation caused by repeated trauma to the anal canal (e.g., constipation) results in increased resting pressure of the internal (involuntary) sphincter. Increased sphincter tone results in a relative ischemia in the region of the fissure, leading to poor healing of the anoderm (Gearhart \& Bulkley, 2005). This causes more pain, which increases anal tone and a chronic "vicious circle" takes place. Chronic anal fissures do not respond to conservative treatment and tend to persist for more than 6 weeks (Lund \& Scholefield, 1996). In a rather ingenious study, Garrido et al. (2005) showed that local injection of gonyautoxins (PST analogues) in the internal sphincter of patients suffering from this condition was safe and effective in the treatment of chronic anal fissures. In their trial, 50 patients with an anal fissure history were subjected to the treatment with a mixture of gonyautoxins 2 and 3 , purified from shellfish highly contaminated with PST, and collected in Chilean Patagonia fjords. Toxins were locally infiltrated in both sides of the fissure, directly in the internal anal sphincter. The healing criteria and primary endpoints of the study were pain relief and fissure epithelisation. The authors observed the total remission of acute and chronic anal fissures within 15 and 28 days, respectively. Ninety-eight percent of the patients healed before 28 days, with a mean time healing of $17.6 \pm 9$ days. Only one relapsed during 14 months of follow-up. Neither faecal incontinence nor other side effects were observed. All patients showed immediate sphincter relaxation. The authors concluded that gonyautoxin breaks the vicious circle of pain and spasm that leads to anal fissure and proposed gonyautoxin anal sphincter infiltration as a safe and effective alternative therapeutic approach to conservative and surgical therapies for anal fissures (Garrido et al., 2005).

From the abovementioned study, it also became evident that local injection of PST induced an effective anaesthetic effect, as evaluated by the pain relief evoked by the patients shortly after sphincter injection of toxins (Lagos, person. comm.). A few years later, the same researchers conducted a randomised, double-blind, placebocontrolled trial in healthy volunteers to evaluate the local anaesthetic effect of neosaxitoxin (Rodriguez-Navarro et al., 2007). Subcutaneous doses of neosaxitoxin $(50 \mu \mathrm{g})$ were injected in the middle posterior skin of the calf of 10 adults, 
and subsequent anaesthetic effects were evaluated using standardised human sensory analyses and pain scales. According to the authors, an effective and complete local sensory blocking was obtained on the first hour after injection, reverting to normal values after 3 to 24 hours depending on which specific neurosensory parameter was evaluated (warm, cold, pain and mechanical touch perception). This was the first human trial to demonstrate an effective local anaesthetic effect of PST injected subcutaneously.

One last example of PST used in clinical trials concerns its applicability in a chronic head pain syndrome known as tension-type headache (Lattes et al., 2009). The pathophysiologic basis of tension-type headache remains unknown. However, abnormalities of cervical and temporal muscle contraction are likely to exist (Raskin, 2005). Though the exact nature of the dysfunction has not yet been elucidated, relaxation almost always relieves this type of headache. While simple muscle relaxants and/or analgesics such as acetaminophen, aspirin, ibuprofen, or other nonsteroidal anti-inflammatory drugs are useful treatments for most individuals, headaches are more resistant to medication for others, fluctuating in severity and periodically persisting more or less continuously for many days (Raskin, 2005). In the PST human trial, 27 patients suffering from chronic tension-type headaches were locally infiltrated with gonyautoxins $(50 \mu \mathrm{g})$ in ten sites considered as "pain trigger points" (Lattes et al., 2009). EMG recording was performed before and immediately after infiltrations. The healing criteria were the significant decrease in the acute headache pain score and the number of days without headache pain. The authors observed that 19 patients $(70 \%)$ responded successfully to the treatment, reporting immediate effects after infiltration with a decrease in pain score five minutes post-injection and an average of 8 weeks without headache (without a second infiltration or use of any additional analgesic medication). No side effects were reported in the follow-up period. The authors determined that local infiltration of gonyautoxin is safe and effective in relieving pain in patients with chronic tension-type headaches, thus proposing this method as a new therapy for this syndrome. No further developments have been published.

\section{Microcystins}

Unlike PST, microcystins have never been used in human clinical trials. However, experimental studies suggest some therapeutic potentialities associated with microcystis structure/function, such as the potential application of an ADDAderived molecule in the treatment of Parkinson's disease.

Parkinson's disease (PD) is a complex neurodegenerative disorder characterised by resting tremor, rigidity (increased muscular tone), bradykinesia (slow movements), postural instability and gait impairment (Shulman et al., 2011). Highly phosphorylated proteins are a pathological hallmark in the progression of the disease (Arima et al., 1999). The abnormal hyperphosphorylation of pathogenic proteins, such as $\alpha$-synuclein in the Lewy bodies, is believed to be implicated in their misfolding and aggregation (Ross \& Poirier, 2004). Other key processes in PD, such as apoptotic cell death mechanisms (Blum et al., 2001) and neuroinflammation (Hirsch \& Hunot, 2009), are also heavily dependent on phosphorylation.

Phosphatases have been considered in recent years as valid targets for the pharmacological modulation of PD-relevant hyperphosphorylation pathways (Braithwaite et al., 2012). The activity of serine/threonine protein phosphatase PP1 appears to be decreased in PD as a result of nigral dopaminergic neuron degeneration (Brown et al., 2008). This happens because dopamine depletion increases the interaction between PP1 and spinophilin, leading to the hyperphosphorylation of synaptic proteins (Brown et al., 2008).

In 2008, Tappan and Chamberlain (2008) demonstrated that a small molecule based on the ADDA sub-structure of microcystin-LR (MCLR) binds at the PP1 allosteric site with an affinity similar to small peptides derived from PP1 regulatory proteins while increasing PP1 activity by almost $200 \%$. This finding contrasts with the toxicity mechanism of MCLR and analogues, which involves the inhibition of PP1 and other 
serine/threonine-specific phosphatases via interactions between specific groups in the molecular structure of microcystins (ADDA including) and the catalytic subunits of these enzymes (Pereira et al., 2013). More recently, Braithwaite et al. (2012) proposed that this small MCLR-based molecule could be used as a modulating agent of PP1 in PD. By increasing PP1 activity, this agent could be a useful therapeutic approach to normalise protein phosphorylation and treat some PD symptoms. Nevertheless, the activation of PP1 by this ADDA-derived molecule remains to be demonstrated in vitro and in vivo.

Microcystins have a wide range of effects on mammalian cells and exhibit dualistic doseresponse behaviour (Liang et al., 2011; Menezes et al., 2013). In fact, microcystins are cytotoxic for many cell types in vitro (e.g., Batista et al., 2003; Pichardo et al., 2005; Dias et al., 2009; Shimizu et al., 2014), but they also induce cell proliferation at non-cytotoxic levels (Dias et al., 2010; Zhang et al., 2013). In addition, microcystins cause severe hepatotoxicity in vivo (revised in Duy et al., 2000; Apeldoorn et al., 2007), but they are also tumour promoters in experimental animals (Falconer, 1991; Nishiwaki-Matsushima et al., 1992; Humpage et al., 2000). This duality has been correlated with the dose-dependent inhibition or activation of serine/threonine protein phosphatases PP1/PP2A (Gehringer, 2004; Liang et al., 2011).

The inhibition of PP1/PP2A unbalances the phosphorylation status of proteins involved in the cytoskeleton organisation, leading to the disruption of cellular structure that is responsible for the well-known microcystins-induced hepatotoxicity (Toivola \& Eriksson, 1999; Gehringer, 2004; Campos \& Vasconcelos, 2010). The organotropism of microcystins has been attributed to their selective uptake by organic anion transporters polypeptides (OATPs) that are primarily expressed in liver cells (Fischer et al., 2005). However, cells derived from the liver, colon and pancreatic tumours may express OATP1B1/OATP1B3 (Monks et al., 2007). Additionally, it has been reported that OATP1B3 is up-regulated in several cancer types, such as non-small cell lung tumours, prostate cancer and invasive ductal carcinomas in breast cells, compared to normal control tissue (Monks et al., 2007; Obaidat et al., 2012). Monks et al. (2007) demonstrated in the HeLa cell model transfected with functional OATP1B1 and OATP1B3 that subnanomolar levels of microcystins induce potent cytotoxicity, which is mediated by the inhibition of PP2A. This study provided a potential clue to the exploration of microcystins as anti-cancer agents for tumours expressing the OATP transporters.

However, if the cytotoxicity of microcystins, mediated by the inhibition of PP's and targeted to tumour cells through OATPs, at doses that do not affect healthy organs may be exploited as a promising anti-cancer mechanism, can we hypothesise other mechanisms? Can we think about other receptors that are specifically expressed by tumour cells that can be targeted by microcystins or a microcystin-carrier conjugate? Can we think about other intracellular mechanisms induced by microcystins that can trigger tumour cells' death?

In addition to the effects on PP1/PP2A, microcystins induce many other mechanisms associated with oxidative stress, mitochondria dysfunction, apoptosis and cell cycle arrest (Campos \& Vasconcelos, 2010), all of which are potentially useful mechanisms underlying the development of anti-cancer compounds (Costa et al., 2012).

Interestingly, microcystin-LR was found to induce the formation of aberrant mitotic spindles, resembling those formed by taxol (Lankoff et al., 2003), an anti-mitotic compound commonly used in the treatment of breast and ovarian cancers (Gascoigne \& Taylor, 2009). It has already been considered that "a therapy that combines an anti-mitotic agent with an apoptosis-inducer might induce a more potent anti-tumour effect" (Gascoigne \& Taylor, 2009). Considering the multiplicity of the effects triggered by microcystins, the search for their potential application in the development of anti-tumour drugs seems to be an interesting area for future research.

\section{Anatoxins}

Most cyanotoxins have a specific site of action, activating or inhibiting specific pathways in spe- 
cific cells or tissues. These specificities render them quite attractive for drug discovery given that most known pathologies result from the disruption of particular sites or pathways of cell function. The specific mode of action of anatoxins might suggest a potential applicability in cholinergic system disorders.

Myasthenia gravis (MG) is an autoimmune disorder clinically characterised by fluctuating weakness and fatigability of skeletal muscles (Carr et al., 2010). This chronic condition is caused by a decrease in the number of available acetylcholine receptors (AChRs) at the neuromuscular junction due to an antibody-mediated autoimmune attack against components of the muscle membrane, including the AChR (85\% of patients) (Lindstrom et al., 1976).

Acetylcholinesterase (AChE) inhibitors are the first-line treatment in patients with $\mathrm{MG}$. AChE inhibitors produce at least partial improvement in most myasthenic patients, and they are most helpful as the initial therapy in newly diagnosed patients or as a sole long-term treatment of milder disease (Skeie et al., 2010). There is no substantial difference in efficacy among the various anticholinesterase drugs, although neostigmine and pyridostigmine are most widely used (Gilhus et al., 2011). These drugs are carbamates that inhibit hydrolysis of acetylcholine by competing reversibly with acetylcholine for binding to the anionic site of AChE (Yu et al., 2010). Organophosphates (OP) exhibit activity similar to carbamates. Inclusively, they exhibit much more prolonged effects because they act as potent noncompetitive irreversible inhibitors of AChE activity by establishing a covalent bond with the serine hydroxyl group at the active site of AChE (Leibson \& Lifshitz, 2008). However, most OP are highly lipid-soluble agents that cross the blood-brain barrier, inducing not only peripheral overstimulation but also deleterious effects in the central nervous system (Kamanyire \& Karalliedde, 2004). This effect inconveniently limits the use of OP for potential pharmacological applications.

Anatoxin-a(s), however, is an unusual natural hydrophilic OP that specifically inhibits AChE activity only at the periphery level (Mahmood
\& Carmichael, 1986) and is unable to cross the blood-brain barrier (Cook et al., 1989). These properties would avoid the deleterious effects in the central nervous system induced by other OP. Moreover, anatoxin-a(s) exhibits much more prolonged effects on AChE activity than pyridostigmine (Cook et al., 1991). Unfortunately, pharmacokinetic data on anatoxin-a(s) is virtually inexistent and most toxicological studies using this toxin date back to the late 80 s and early 90 s. Anatoxin-a(s) has an LD50 (mice, i.p.) of $20 \mu \mathrm{g}$ $\mathrm{Kg}^{-1}$ of body weight and has been associated with animal toxicosis in several countries (Patoka et al., 2011). Clinical signs of nicotinic receptor overstimulation are most commonly observed before a lethal outcome, including a rapid onset of hypersalivation, lacrimation, tremors, incoordination, convulsions, urinary incontinence and respiratory arrest (Cook et al., 1989; Matsunaga et al., 1989; Puschner \& Roegner, 2012). Further studies are needed to understand if this natural toxin, which is similar in its action to the chemical sarin and soman weapons, could be used in the future with a more beneficial purpose such as MG management.

Cholinergic compounds such as anatoxins may have a role in the search for therapeutic agents for other pathologies involving cholinergic pathway disorders. Alzheimer's disease is associated with decreased levels of several proteins and neurotransmitters in the cerebral cortex, especially acetylcholine, its synthetic enzyme choline acetyltransferase and nicotinic cholinergic receptors. This demential disorder cannot be cured, and no drugs are more effective than cholinesterase inhibitors, which are used for the mere symptomatic management of behavioural problems. Anatoxins act either on cholinergic receptors (anatoxin-a) or on the cholinesterase enzyme (anatoxin-a(s)). In our view, such a highly specific mode of action has not yet been totally explored.

\section{CONCLUSION}

In this paper, we have approached new areas of the cyanobacteria/cyanotoxins-human health 
interception. Cyanotoxins, as well as other secondary metabolites from cyanobacteria, are given their first steps as potential sources of new drugs for medical purposes. The results are promising for one or two compounds, but an immense field of research is still waiting for further developments. One of the major advantages of cyanobacteria as a natural source for active compounds lies in the economy of their cultivation, even compared with other microorganisms. Being oxygenic autotrophs, cyanobacteria require only sunlight and simple inorganic mediums for growth. Cyanobacteria populate diverse habitats throughout the world and are relatively easy to collect and manipulate. Therefore, their potential for biotechnology deserves more scientific attention and interdisciplinary research.

\section{ACKNOWLEDGMENTS}

We acknowledge Professor Maria Angeles Puig for her kind revision of the abstract in Spanish. We also acknowledge the Portuguese Foundation for Science and Technology for the grant SFRH/BPD/77981/2011 attributed to Elsa Dias.

\section{REFERENCES}

ADAMS, C. P. \& V. V. BRANTNER. 2006. Estimating the cost of new drug development: is it really \$802 million? Health Affairs, 25(2): 420-428.

APELDOORN, M. E., H. P. EGMOND, G. J. A. SPEIJERS \& G. J. I. BAKKER. 2007. Toxins of cyanobacteria. Molecular Nutrition \& Food Research, 51: 7-60.

ARIMA, K., S. HIRAI, N. SUNOHARA, K. AOTO, Y. IZUMIYAMA, K. UÉDA, K. IKEDA \& M. KAWAI. 1999. Cellular co-localization of phosphorylated tau- and NACP/alpha-synucleinepitopes in Lewy bodies in sporadic Parkinson's disease and in dementia with Lewy bodies. Brain Research, 843: 53-61.

BATISTA, T., G. DE SOUSA, J. S. SUPUT, R. RAHMANI \& D. SUPUT. 2003. Microcystin-LR causes the collapse of actin filaments in primary human hepatocytes. Aquatic Toxicology, 65: 85-91.

BATORÉU, C., E. DIAS, P. PEREIRA \& S. FRANCA. 2005. Risk of human exposure to paralytic shellfish toxins of algal origin. Environmental Toxicology and Pharmacology, 19: 401-406.

BLUM, D., S. TORCH, N. LAMBENG, M. NISSOU, A. L. BENABID, R. SADOUL \& J. M. VERNA. 2001. Molecular pathways involved in the neurotoxicity of 6-OHDA, dopamine and MPTP: contribution to the apoptotic theory in Parkinson's disease. Progress in Neurobiology, 65: 135-172.

BRAITHWAITE, S. P., M. VORONKOV, J. B. STOCK, M. M. MOURADIAN. 2012. Targeting phosphatases as the next generation of disease modifying therapeutics for Parkinson's disease. Neurochemistry International, 61: 899-906.

BROWN, A. M., A. J. BAUCUM, M. A. BASS \& R. J. COLBRAN. 2008. Association of protein phosphatase $1 \mathrm{y} 1$ with spinophilin suppresses phosphatase activity in a Parkinson disease model. Journal of Biological Chemistry, 283: 14286-14294.

BURCH, M. D. 2008. Effective doses, guidelines and regulations. In: Cyanobacterial harmful blooms State of the science and research needs. H. K. Hudnell (ed.): 831-53. Springer Science, NC, USA.

CAMPOS, A. \& V. VASCONCELOS. 2010. Molecular Mechanisms of Microcystin Toxicity in Animal Cells. International Journal of Molecular Sciences, 11: 268-287.

CARR, A. S., C. R. CARDWELL, P. O. McCARRON \& J. McCONVILLE. 2010. A systematic review of population based epidemiological studies in Myasthenia Gravis. BMC Neurology, 10: 46.

CESTÈLE, S. \& W. A. CATTERALL. 2000. Molecular mechanisms of neurotoxin action on voltagegated sodium channels. Biochimie, 82: 883-892.

CHORUS, I., I. R. FALCONER, H. J. SALAS \& J. BARTRAM. 2000. Health risks caused by freshwater cyanobacteria in recreational waters. Journal of Toxicology and Environmental Health, Part $B, 3: 323-347$.

CODD, G. A., S. M. F. O. AZEVEDO, S. N. BAGCHI, M. D. BURCH, W. W. CARMICHAEL, W. R. HARDING, K. KAYA \& H. C. UTKILEN. 2005. Cyanonet: A Global Network for Cyanobacterial Bloom and Toxin Risk Management- Initial Situation Assessment and Recommendations. IHP-VI Technical Document in Hydrology, No 76. UNESCO Working Series, SC-2005/WS/55, Paris.

COOK, W. O., V. R. BEASLEY, R. A. LOVELL, A. M. DAHLEM, S. B. HOOSER, N. A. MAHMOOD \& W. W. CARMICHAEL. 1989. Consistent inhibition of peripheral cholinesterases by neurotoxins from the freshwater cyanobacterium 
Anabaena flos-aquae: studies of ducks, swine, mice and a steer. Environmental Toxicology and Chemistry, 8(10): 915-922.

COOK, W. O., A. M. DAHLEM, K. S. HARLIN, V. R. BEASLEY, S. B. HOOSER, W. M. HASCHEK \& W. W. CARMICHAEL. 1991. Reversal of cholinesterase inhibition and clinical signs and the postmortem findings in mice after intraperitoneal administration of anatoxin-a(s), paraoxon or pyridostigmine. Vetebrate and Human Toxicology, 33(1): $1-4$.

COSTA, M., J. COSTA-RODRIGUES, M. H. FERNANDES, P. BARROS, V. VASCONCELOS \& R. MARTINS. 2012. Marine Cyanobacteria Compounds with Anticancer Properties: A Review on the Implication of Apoptosis. Marine Drugs, 10: 2181-2207.

DEEDS, J. R., J. H. LANDSBERG, S. M. ETHERIDGE, G. C. PITCHER \& S. W. LONGAN. 2008. Non-Traditional Vectors for Paralytic Shellfish Poisoning. Marine Drugs, 6: 308-348.

DIAS, E., M. ANDRADE, E. ALVERCA, P. PEREIRA, M. C. C. BATORÉU, P. JORDAN \& M. J. SILVA. 2009. Comparative study of the cytotoxic effect of microcistin-LR and purified extracts from Microcystis aeruginosa on a kidney cell line. Toxicon, 53: 487-495.

DIAS, E., P. MATOS, P. PEREIRA, M. C. C. BATORÉU, M. J. SILVA \& P. JORDAN. 2010. Microcystin-LR activates the ERK1/2 kinases and stimulates the proliferation of the monkey kidney derived cell line Vero-E6. Toxicology in Vitro, 24: 1689-1695.

DUY, T. N., P. K. S. LAM, G. R. SHAW \& D. W. CONNELL. 2000. Toxicology and risk assessment of freshwater cyanobacterial (blue-green algae) toxins in water. Reviews of Environmental Contamination and Toxicology, 163: 113-186.

EDELMAN, M. J., D. R. GANDARA, P. HAUSNER, V. ISRAEL, D. THORNTON, J. DESANTO \& L. A. DOYLE. 2003. Phase 2 study of cryptophycin 52 (LY355703) in patients previously treated with platinum based chemotherapy for advanced nonsmall cell lung cancer. Lung Cancer, 39(2): 197199.

FALCONER, I. R. 1991. Tumour promotion and liver injury caused by oral consumption of cyanobacteria. Environmental Toxicology and Water Quality, 6: 177-184.

FISCHER, W. L., S. ALTHEIMER, V. CATTORI, P. J. MEIER, D. R. DIETRICH \& B. HAGENBUCH.
2005. Organic anion transporting polypeptides expressed in liver and brain mediate uptake of microcystin. Toxicology and Applied Pharmacology, 203: 257-263.

FUNARI, E. \& E. TESTAI. 2008. Human health risk assessment related to cyanotoxins exposure. Critical Reviews in Toxicology, 38: 97-125.

GARRIDO, R., N. LAGOS, K. LATTES, M. ABEDRAPO, G. BOCIC, A. CUNEO, H. CHIONG, C. JENSEN, R. AZOLAS, A. HENRIQUEZ \& C. GARCIA. 2005. Gonyautoxin: New Treatment for Healing Acute and Chronic Anal Fissures. Diseases of the Colon \& Rectum, 48: 335-343.

GASCOIGNE, K. E. \& S. S. TAYLOR. 2009. How do anti-mitotic drugs kill cancer cells? Journal of Cell Science, 122: 2579-2585.

GEARHART, S. L \& G. BULKLEY. 2005. Common diseases of the colon and anorectum and mesenteric vascular insuffiency. In: Harrison's Principles of Internal Medicine $\left(16^{\text {th }}\right.$ Edition). D. L. Kaspar (ed.): 1795-1803. McGraw-Hill, London, UK.

GEHRINGER, M. M. 2004. Microcystin-LR and okadaic acid-induced cellular effects: a dualistic response. FEBS Letters, 557: 1-8.

GILHUS, N. E., J. F. OWE, J. M. HOFF, F. ROMI, G. O. SKEIE \& J. A. AARLI. 2011. Myasthenia Gravis: A Review of Available Treatment Approaches. Autoimmune Diseases, doi: 10.4061/ 2011/847393

GOYAL, R. 2005. Diseases of the esophagus. In: Harrison's Principles of Internal Medicine $\left(16^{\text {th }}\right.$ Edition). D. L. Kaspar (ed.): 1739-1746. McGrawHill, London, UK.

HIRSCH, E. C. \& S. HUNOT. 2009. Neuroinflammation in Parkinson's disease: a target for neuroprotection? Lancet Neurology, 8: 382-397.

HOLLAND, A. \& S. KINNEAR. 2013. Interpreting the Possible Ecological Role(s) of Cyanotoxins: Compounds for Competitive Advantage and/or Physiological Aide? Marine Drugs, 11: 2239-2258.

HUMPAGE, A. R., S. J. HARDY, E. J. MOORE, S. M. FROSCIO \& I. R. FALCONER. 2000. Microcystins (cyanobacterial toxins) in drinking water enhance the growth of aberrant crypt foci in the mouse colon. Journal of Toxicology and Environmental Health A, 61: 155-65.

IARC. 2006. Cyanobacterial peptide toxins. Available at: http://monographs.iarc.fr/ENG/Meetings/94-cyanobacteria.pdf. 
KAMANYRE, R. \& L. KARALLIEDDE. 2004. Organophosphate toxicity and occupational exposure. Occupational Medicine, 54: 69-75.

KAO, C. Y. 1966. Tetrodotoxin, saxitoxin and their significance in the study of excitation phenomenon. Pharmacological Reviews, 18: 997-1049.

LANKOFF, A., A. BANASIK, G. OBE, M. DEPERAS, K. KUZMINSKI, M. TARCZYNSKA, T. JURCZAK \& A. WOJCIK. 2003. Effect on microcystin-LR and cyanobacterial extract from Polish reservoir of drinking water on cell cycle progression, mitotic spindle, and apoptosis in CHO-K1 cells. Toxicology and Applied Pharmacology, 189: 204-213.

LATTES, K., P. VENEGAS, N. LAGOS, M. LAGOS, L PEDRAZA, A. J. RODRIGUEZ-NAVARRO \& C. GARCIA. 2009. Local infiltration of gonyautoxin is safe and effective in treatment of chronic tension-type headache. Neurological Research, 31 : 228-233.

LEIBSON, T. \& M. LIFSHITZ. 2008. Organophosphate and carbamate poisoning: review of the current literature and summary of clinical and laboratory experience in Southern Israel. The Israel Medical Association Journal, 10: 767-70.

LI, H., P. XIE, G. LI, L. HAO \& Q. XIONG. 2009. In vivo study on the effects of microcystin extracts on the expression profiles of proto-oncogenes (cfos, c-jun and c-myc) in liver, kidney and testis of male Wistar rats injected i.v. with toxins. Toxicon, 53: 169-175.

LIANG, J., T. LI, Y. ZHANG, Z. GUO \& L. XU. 2011. Effect of microcystin-LR on protein phosphatase $2 \mathrm{~A}$ and its function in human amniotic epithelial cells. $J$ Zhejiang University-Sciences B (Biomedicine \& Biotechnology), 12: 951-960.

LINDSTROM, J. M., M. E. SEYBOLD, V. A. LENNON, S. WHITTINGHAM \& D. D. DUANE. 1976. Antibody to acetylcholine receptor in myasthenia gravis. Prevalence, clinical correlates, and diagnostic value. Neurology, 26: 1054-1059.

LU, K., J. DEMPSEY, R. M. SCHULTZ, C. SHIH \& B. A. TEICHER. 2001. Cryptophycin-induced hyperphosphorylation of Bcl-2, cell cycle arrest and growth inhibition in human H460 NSCLC cells. Cancer Chemotherapy and Pharmacology, 47(2): 170-178.

LUND, J. N. \& J. H. SCHOLEFIELD. 1996. Aetiology and treatment of anal fissure. British Journal of Surgery, 83: 1335-1344.
MAHMOOD, N. A. \& W. W. CARMICHAEL. 1986. The pharmacology of anatoxin-a(s), a neurotoxin produced by the freshwater cyanobacterium $A n$ abaena flos-aquae NRC 525-17. Toxicon, 24(5): 425-434.

MATSUNAGA, S., R. E. MOORE, W. P. NIEMCZURA \& W. W. CARMICHAEL. 1989. Anatoxin-a(s), a potent anticholinesterase from Anabena flos-aquae. Journal of American Chemistry Society, 111(20): 8021-8023.

MENEZES, C., E. VALÉRIO \& E. DIAS. 2013. The Kidney Vero-E6 Cell Line: A Suitable Model to Study the Toxicity of Microcystins. In: New Insights into Toxicity and Drug Testing. S. Gowder (ed.): 29-48. InTech. Rijeka, Croatia.

MEREL, S., M. C. VILLARÍN, K. CHUNG \& S. SNYDER. 2013. Spatial and thematic distribution of research on cyanotoxins. Toxicon, 76: 118-131.

MONKS, N. R., S. LIU, Y. XU, H. YU, A. BENDELOW \& J. A. MOSCOW. 2007. Potent cytotoxicity of the phosphatase inhibitor microcystin LR and microcystin analogues in OATP1B1- and OATP1B3-expressing HeLa cells. Molecular Cancer Therapeutics, 6: 587-598.

NEWMAN, D. J. \& G. M. CRAGG. 2012. Natural products as sources of new drugs over the 30 years from 1981 to 2010. Journal of Natural Products, 75: 311-335.

NISHIWAKI-MATSUSHIMA, R., T. OHTA, S. NISHIWAKI, M. SUGANUMA, K. KOHYAMA, T. ISHIKAWA, W. W. CARMICHAEL1 \& H. FUJIKI. 1992. Liver tumor promotion by the cyanobacterial cyclic peptide toxin microcystinLR. Journal of Cancer Research and Clinical Oncology, 118: 420-424.

OBAIDAT, A., M. ROTH, B. HAGENBUCH. 2012. The Expression and Function of Organic Anion Transporting Polypeptides in Normal Tissues and in Cancer. Annual Review of Pharmacology and Toxicology, 52: 135-151.

PATOCKA, J., R. C. GUPTA \& K. KUCA. 2011. Anatoxin-a(s): Natural Organophosphorus anticholinesterase agent. Military Medical Science Letters, 80: 129-139.

PEREIRA, S. R., V. M. VASCONCELOS \& A. ANTUNES. 2013. Computational study of the covalent bonding of microcystins to cysteine residues - a reaction involved in the inhibition of the PPP family of protein phosphatases. FEBS Journal, 280: 674-680. 
PICHARDO, S., A. JOS, J. L ZURITA, M. SALGUERO, A. M. CAMEAN \& G. REPETTO. 2005. The use of the fish cell lines RTG-2 and PLHC-1 to compare the toxic effects produced by microcystins LR and RR. Toxicology In Vitro, 19: 865-873.

PUSCHNER, B. \& A. ROEGNER. 2012. Cyanobacterial (bluegreen algae) toxins. In Veterinary Toxicology: Basic and Clinical Principles. R. C. Gupta (ed.): 953-965. Academic Press/Elsevier. Amsterdam, Nederland.

RASKIN, N. H. 2005. Headache. In: Harrison's Principles of Internal Medicine (16 ${ }^{\text {th }}$ Edition). D. L. Kaspar (ed.): 85-94. McGraw-Hill. London. UK.

RODRIGUEZ-NAVARRO, A. J., N. LAGOS, M. LAGOS, I. BRAGHETTO, A. CSENDES, J. HAMILTON, Z. BERGER, G. WIEDMAIER, A. HENRIQUEZ. 2006. Intrasphincteric neosaxitoxin injection: evidence of lower esophageal sphincter relaxation in achalasia. American Journal of Gastroenterology, 101: 2667-2668.

RODRIGUEZ-NAVARRO, A. J., N. LAGOS, M. LAGOS, I. BRAGHETTO, A. CSENDES, J. HAMILTON, C. FIGUEROA, D. TRUAN, C. GARCIA, A. ROJAS, V. IGLESIAS, L. BRUNET \& F ALVAREZ. 2007. Neosaxitoxin as a Local Anesthetic-Preliminary Observations from a First Human Trial. Anesthesiology, 106: 339-45.

ROSS, C. \& M. POIRIER. 2004. Protein aggregation and neurodegenerative disease. Nature Medicine, 10(Suppl.): S10-S17.

SHIMIZU, K., T. SANO, R. KUBOTA, N. KOBAYASHI, M. TAHARA, T. OBAMA, N. SUGIMOTO, T. NISHIMURA \& Y. IKARASHI. 2014. Effects of the Amino Acid Constituents of Microcystin Variants on Cytotoxicity to Primary Cultured Rat Hepatocytes. Toxins, 6: 168-179.

SHULMAN, J., P. L. DE JAGER \& M. B. FEANY. 2011. Parkinson's Disease: Genetics and Pathogenesis. Annual Review of Pathology Mechanism of Disease, 6: 193-222.

SINGH, R. K., S. P. TIWARI, A. K. RAI, T. M. MOHAPATRA. 2011. Cyanobacteria: an emerging source for drug discovery. The Journal of Antibiotics, 64: 401-412.

SKEIE, G. O., S. APOSTOLSKI, A. EVOLI, N. E. GILHUS, I. ILLA, L. HARMS, D. HILTONJONES, A. MELMS, J. VERSCHUUREN \& H. W. HORGE. 2010. Guidelines for treatment of autoimmune neuromuscular transmission disorders.
European Journal of Neurology, 17(7): 893-902.

SMITH, C. D., X. ZHANG, S. L. MOOBERRY, G. M. PATTERSON \& R. E. MOORE. 1994. Cryptophycin: a new antimicrotubule agent active against drug-resistant cells. Cancer Research, 54(14): 3779-3784.

SPOOF, L. 2005 Microcystins and nodularins. In: TOXIC: cyanobacterial monitoring and cyanotoxin analysis. J. Meriluoto \& A. G. Codd (ed.): 17. Åbo Akademi University. Turku, Finland.

TAPPAN, E. \& A. R. CHAMBERLIM. 2008. Activation of protein phosphatase 1 by a small molecule designed to bind to the enzyme's regulatory site. Chemical Biology, 15: 167-174.

TING, P. T. \& A. FREIMAN. 2004. The story of Clostridium botulinum: from food poisoning to Botox. Clinical Medicine, 4: 258-261.

TOIVOLA, D. M. \& J. E. ERIKSSON. 1999. Toxins Affecting Cell Signaling and Alteration of Cytoskeletal Structure. Toxicology in Vitro, 13: 521530.

U.S. EPA. 2006. IRIS Toxicological Review of Cyanobacterial Toxins: Microcystins LR, RR, YR and LA (External Review Draft). EPA/600/R-06/139. U.S. Environmental Protection Agency. Washington, USA.

WIESE, M., P. M. D'AGOSTINO, T. K. MIHALI, M. C. MOFFITT \& B. A. NEILAN. 2010. Neurotoxic Alkaloids: Saxitoxin and Its Analogs. Marine Drugs, 8: 2185-2211.

YU, Q., H. W. HOLLOWAY, W. LUO, D. K. LAHIRI, A. BROSSI \& N. H. GREIG. 2010. Long-acting anticholinesterases for myasthenia gravis: synthesis and activities of quaternary phenylcarbamates of neostigmine, pyridostigmine and physostigmine. Bioorganic \& Medicinal Chemistry, 18(13): 4687-4693.

WHO. 2013. World Health Statistics 2013 - Part 1, Health-related Millenium Development Goals. Available at: http://www.who.int/gho/publications/ world_health_statistics/EN_WHS2013_Part1.pdf

ZHANG, X., P. XIE, X. ZHANG, W. ZHOU, S. ZHAO, Y. ZHAO \& Y. CAIB. 2013. Toxic effects of microcystin-LR on the HepG2 cell line under hypoxic and normoxic conditions. Journal of Applied Toxicology, 33: 1180-1186.

ŽEGURA, B., A. ŠTRASER, M. FILIPČ. 2011. Genotoxicity and potential carcinogenicity of cyanobacterial toxins -a review. Mutation Research, 727: 16-41. 